\title{
ZASNOVA PROSTORSKEGA INFORMACIJSKEGA SISTEMA (PIS/GIS) KOT PODLAGE ZA VEČNAMENSKO GOSPODARJENJE Z GOZDOM IN GOZDNATO KRAJINO
}

\author{
Milan Hočevar, David Hladnik in Marko Kovač
}

Izvleček

UDK 630:91:681.3

Smotrno in trajno gospodarjenje $z$ gozdom in gozdnim prostorom zahteva dobro poznavanje njunega stanja in razvojnih teženj. Zato je gozdarstvo ena redkih panog, ki že stoletja zbira velike količine podatkov, posebno $v$ zadnjih letih pa skuša za potrebe načrtovanja oblikovati celosten informacijski sistem. Dosedanji informacijski sistem so sestauljali predusem popis znakov in dendrometrijska inventura $v$ ureditvenih enotah ter gozdarska kartografija. Širjenju podatkounih baz ni sledil tudi uraunotežen razvoj informacijske tehnologije, zaradi čedalje bolj obremenjenega okolja in propadanja gozdov pa je potrebno težišče dela prenesti na učinkovit monitoring dogajanj $v$ gozdu in gozdnem prostoru. Zasnova sodobnega prostorskega informacijskega sistema mora poleg integracije dosedanjega sistema zbiranja podatkov $v$ gozdarstvu upoštevati vedno bolj poudarjeno mnogonamensko vlogo gozda in naš sonaraven, prostorsko izredno razčlenjen način gospodarjenja. Zaradi racionalnosti mora biti pridobivanje podatkov čim cenejše, uporaba informacij pa čim bolj široka, kar ponazarjajo predstavljena načela večplastnosti, polifunkcionalnosti, prostorske celovitosti in multitemporalnosti.

UDC 630:91:681.3

Abstract

CONCEPTS OF SPATIAL INFORMATION SYSTEM (SIS/GIS) AS A BASIS FOR THE MULTIPURPOSE MANAGEMENT OF THE FOREST AND FOREST LANDSCAPE

The goal of the Geographic Information Systems in forestry is to improve efficiency and effectiveness in decision making regarding the regulation, protection and management of environmental resources. In order to carry out relevant analyses in the system of co-natural forest management, to record changes and damage to our forests, and to allow us to make constructive use of the resources available, the integration of spatial and factual data is necessary. The principles of the structure of modern spatial information systems and the concept of a comprehensive forest inventory as its integral part are described.

\section{POMEN INFORMATIKE V GOZDARSTVU}

Gospodarjenje s krajino in naravnimi viri se izraža $z$ nenehno interakcijo med človekovimi zahtevami do okolja in njegovim smotrnim izkoriščanjem.

Dr. M. Hočevar, mag. D. Hladnik, mag. M. Kovač, Biotehniška fakulteta, Oddelek za gozdarstvo in IGLG, Ljubljana. 
To razmerje sodi $\mathrm{v}$ širši kontekst razvojnih paradigem, ki jih oblikujejo najrazličnejše silnice, med katerimi so najpomembnejše "preživetje človeka kot vrste" in pa moralno-etični vidiki, ki človeku kot delu stvarstva onemogočajo nenadzorovano početje $\mathrm{v}$ prostoru in času. Za današnji svet se zaradi naglega znanstvenega, tehnološkega in ekonomskega razvoja zdita sprejemljivi COLBYJEVI (Golob, 1992) paradigmi "gospodarjenje $z$ viri" in "ekorazvoj", ki ju že nekaj časa oblikuje tudi gozdarska stroka in ju je mogoče povsem vključiti v sodobni načrtovalski proces. Učinkovitega načrtovanja naravnih virov, ki poleg dobrin upošteva še bioekološke danosti in vrsto interakcij med naravo in družbo, si ni mogoče zamišljati brez kakovostnih informacij o njihovem stanju in prihodnjem potencialu. Informacije so tudi podlaga za konsistenten program družbenogospodarskega razvoja, predvsem pa predpogoj za smotrno odločanje na vseh strateško pomembnih načrtovalskih ravneh.

Gozdarstvo je ena izmed redkih panog, ki že stoletja zbira podatke o gozdu in gozdnem prostoru. Rezultat načrtnega dela so obsežne podatkovne zbirke, ki obravnavajo praktično vse slovenske gozdove, v časovnem smislu pa segajo daleč $v$ preteklost. Razvrstimo jih lahko $v$ dve osnovni kategoriji: $\mathbf{v}$ kategorijo vsebinskih (atributivnih) in $\mathrm{v}$ kategorijo prostorskih podatkov. Prva obsega količinske in kakovostne podatke, ki v obliki teksta, tabel, seznamov in kod opisujejo posamezne elemente prostora in površine. V drugo kategorijo večinoma uvrščamo kartografske predloge in razne tematske karte.

Vzdrževanje klasičnega sistema informacij je časovno zelo zahtevno in drago. Ker pretežno še temelji na manualni tehniki, kljub računalniški podpori $v$ posameznih fazah dela, je počasno in ima omejene možnosti za učinkovito racionalizacijo. Predvsem pa je klasično zasnovan sistem nebogljen, ko je treba obdelati prostorsko orientirane podatke in informacije, kar je poleg zahtev po njihovem hitrem in ažurnem posredovanju osrednji problem učinkovitega načrtovanja. Oboje nam nudijo računalniško podprti prostorski informacijski sistemi ( $\mathrm{v}$ nadaljevanju PIS). Razvoj tovrstnih sistemov se je začel $v$ sedemdesetih letih. Danes le-ti že omogočajo hitre in kombinirane obdelave podatkov in informacij ter njihovo predstavitev $v$ kartografski in tekstovni obliki. Glede na to, da so vse informacije geokodirane (prostorsko opredeljene), je $\mathrm{z}$ orodji mogoče reševati eksaktno definirane probleme oz. naloge. Nekatere med njimi so:

- kakšna je lesna zaloga smrekovih sestojev v višinskem pasu med 1000 in $1500 \mathrm{~m}$, v poljubnem območju s koordinatami $\mathrm{x}$ in $\mathrm{y}$ ?

- na katerih lokacijah (nadmorska višina, ekspozicija, drevesna sestava) se pojavljajo nadpovprečne poškodbe gozdnih sestojev?

- kolikšen je delež gozdne površine in kakšna je struktura lesne zaloge v pasu, ki od najbližje kamionske ceste ni oddaljen več kot 200 m? 


\section{VRSTE IN ZGRADBA PROSTORSKIH INFORMACIJSKIH SISTEMOV}

\section{DEFINICIJA IN FUNKCIJE PIS}

Prostorski informacijski sistemi so orodje za vsestransko hitro obdelavo velike količine raznovrstnih prostorskih podatkov in informacij. So računalniško podprti avtomatski informacijski sistemi, vendar pa pri uporabi od uporabnika ne zahtevajo specializiranega računalniškega znanja. Omogočajo ažurno, selektivno in hitro pridobivanje informacij, njihovo obdelavo in posredovanje geokodiranih informacij, ki so podlaga za smotrno gospodarjenje $\mathrm{z}$ naravnimi viri in prostorom. Vse informacije so večplastno združljive, prav tako so združljive tudi s tujimi podatkovnimi zbirkami.

PIS združuje lastnosti sistemov za upravljanje s podatkovnimi bazami, $\mathbf{s}$ sistemi za računalniško grafiko in avtomatsko kartografijo. Je pa še mnogo več. Vsebuje namreč še orodja za simultano, soodvisno upravljanje $\mathbf{s}$ prostorskimi in atributivnimi podatki, ki se nanašajo na isto lokacijo. Tako npr. vsaki grafični spremembi avtomatsko sledi tudi sprememba vsebinskih podatkov $v$ ustreznih podatkovnih zbirkah. Najpomembnejše funkcije, ki jih sodobni PIS-i omogočajo pri gospodarjenju $z$ gozdovi, je mogoče povzeti takole:

- integracija podatkov iz različnih podatkovnih virov $\mathrm{v}$ skupne baze podatkov (teren, karta, slika),

- integracija kart, narejenih $v$ različnih merilih in projekcijah, $v$ karte želenega formata, tematike in merila,

- izračun površin, pretvorba projekcij, sprememba meril, sprememba vsebine kart,

- vzpostavljanje relacij med neodvisnimi in mnogokrat iz različnih virov pridobljenimi podatki preko sistema geokodiranja; $s$ tem je omogočeno pridobivanje povsem novih informacij,

- sposobnost agregiranja podatkov od podrobnega informacijskega nivoja na regionalno ali državno raven; s posebnimi algoritmi tvori sistem iz podrobnih podatkov (nanašajočih se na osnovne informacijske enote) podatkovne baze za stratume na višji načrtovalski ravni,

- avtomatska izdelava novih tematskih kart in podatkovnih zbirk na podlagi presekov (prekrivanja) posameznih podatkovnih ravni,

- avtomatsko določanje sosedskih pasov vzdolž izbranih linij ali poligonov (npr.: določanje površin upoštevaje s pravilno razdaljo ali določanje emisijskega pasu vzdolž avtoceste itn.).

\section{SESTAVINE PIS}

Prostorske informacijske sisteme sestavljajo strojna in programska oprema, podatki in uporabniki. PIS zahteva, da so vsi podatki prostorsko opredeljeni (s koordinatami $x, y$ ). Samo enoličen zapis omogoča njihovo kasnejše prepoznavanje, ne glede na to, ali so $v$ sistemu zapisani kot točke, linije 
ali poligoni. V principu je PIS sestavljen iz več med seboj povezanih podsistemov.

Podsistem za zajemanje podatkov obsega pripravo, organizacijo in snemanje podatkov. Vhodni podatki so $\mathrm{v}$ grafični (razne karte) ali alfanumerični (tekstovni) obliki in so $s$ primernimi orodji transformirani $v$ za računalnik prepoznavne digitalne oblike. Poleg terenskih so bistveni vir prostorskih podatkov še aeroposnetki, v zadnjem času pa vedno bolj tudi satelitski posnetki. Vnos podatkov poteka običajno po ločenih podatkovnih slojih z digitalizacijo, skaniranjem ali kodiranjem na računalniške spominske medije.

Podsistem za upravljanje s podatkovnimi bazami obsega kontrolo, shranjevanje in obdelavo podatkov. Sistem omogoča strukturiranje, dopolnjevanje, združevanje in transformacijo podatkov, spajanje kartnih izsekov in geometrične korekcije.

Podsistem za analizo podatkov omogoča geografsko analizo, interpretacijo podatkov ter izdelavo modelnih študij in simulacij. Obdelave obsegajo prostorske, vsebinske ali kombinirane podatke. V tej fazi je možna tudi njihova agregacija. Tipična operacija je npr. generiranje novih informacij s prekrivanjem izbranih podatkovnih slojev ob hkratnem izračunu površin in razdalj ter izdelava ustreznih vsebinskih datotek in novih tematskih kart $\mathrm{v}$ izbranem merilu in tehniki.

Podsistem za izhod podatkov in prikaz rezultatov omogoča grafično, kartografsko ali tekstovno predstavitev na različnih izhodnih enotah (tabele, grafi, karte). Današnja tehnika na področju grafičnih prikazov in kartografije skorajda ne postavlja nobenih omejitev. Nasprotno, omogoča izpise različnih formatov (do $A$ ) $v$ črnobeli ali barvni tehniki, $z$ visoko resolucijo (do 256 različnih barvnih odtenkov) neposredno $z$ računalnika, oziroma preko skanerjev. Zadržanost glede uporabe slednje je umestna, ker zahteva nabava take opreme tudi visoka sredstva.

Glede na način shranjevanja grafičnih podatkov obstajata dva načina: rastrski in vektorski zapis. Oba imata prednosti in pomanjkljivosti, zato mnogi komercialni PIS programi že nudijo možnost pretvorbe zapisa iz ene oblike $v$ drugo. Prednost vektorskih sistemov je $v$ natančnem linijskem zapisu, kar je pomembno v kartografiji, rastrski sistemi pa so enostavnejši. Nekatere baze podatkov obstajajo samo $v$ rastrski obliki (npr. skanirani podatki satelitskih snemanj).

\section{ORIS OBSTOJEČE GOZDARSKE INFORMATIKE}

Biološka narava gozda in pa dolga proizvodna obdobja sta najpomembnejša razloga, zaradi katerih je gozdarska stroka že pred več kot stoletjem začela načrtno urejati gozdni prostor in vzdrževati gozdno proizvodnjo (Funk1, 1979). Filozofsko načelo trajnosti, ki ga je sooblikovala in tudi 
sprejela za svoj temeljni postulat, ji je bilo pri njenem delu $v$ veliko pomoč in oporo. Upoštevaje ta izhodišča in nekatera, že omenjena $v$ uvodnih besedah, sploh ne preseneča sorazmerno zgodaj postavljena zahteva po vzpostavitvi gozdarskega informacijskega sistema. Le-ta naj bi $v$ prvi vrsti zadostil potrebam urejevalcev (načrtovalcev) gozdnega prostora, rabil pa bi tudi strokovnim službam $v$ gozdarstvu in zunaj njega. Obstoječi informacijski sistem naj bi gozdarstvu pomagal predvsem pri izpeljavi naslednjih vsebinskih nalog (Mikulič, 1983, 1987, 1992):

- zagotavljanje trajnih funkcij gozda $z$ upoštevanjem medsebojne povezanosti in soodvisnosti naravnih, gospodarskih in splošnodružbenih dejavnikov,

- povezava sistema $z$ večravninskim sistemom gozdnogospodarskega načrtovanja (načrti gozdnogospodarskih območij, gozdnogospodarskih enot in podrobni gojitveni načrti),

- pridobitev strokovnih osnov za celovit sistem "družbenega" planiranja in pomoč pri usklajevanju in razmejevanju širšega družbenega interesa za gozdove od ostalih interesov,

- načrtno zbiranje podatkov o stanju $v$ gozdovih, nadzor nad učinki gospodarjenja (preverjanje razvojne dinamike gozda),

- oceno optimalne izkoriščenosti rastiščnega potenciala upoštevaje strokovna izhodišča $\mathrm{v}$ celotnem slovenskem gozdnem prostoru.

Naštetim nalogam, ki so trajno navzoče že od konca sedemdesetih let, so se. v preteklem desetletju pridružile še nove. Pravi šok je npr. doživelo gozdarstvo in $z$ njim celotna slovenska javnost $z$ razširitvijo propadanja gozdov $\mathrm{v}$ našo deželo. Ta je najprej sprožil polemiko, nazadnje pa odločitev, da tudi $\mathbf{v}$ Sloveniji pristopimo $\mathbf{k}$ organiziranemu monitoringu tega procesa. Kljub dejstvu, da je bil v gozdarstvu tisti čas že organiziran operativen gozdarski informacijski sistem, se je vendarle izkazalo, da nove naloge ne bo mogel zadovoljivo opraviti, vsaj ne $v$ tako kratkem času, kot ga je zahtevala metoda snemanja. Zaradi tega je bil zasnovan in vzpostavljen nov sistem, ki v primerjavi s starejšim (gozdarskim informacijskim sistemom) temelji na statistični zasnovi. Slovensko gozdarstvo tako ta čas vodi dva sistema: gozdarski informacijski sistem, ki rabi predvsem gozdnogospodarskemu načrtovanju, in pa popis poškodovanosti gozdov, ki je namenjen monitoringu zdravstvenega stanja gozdov.

\section{OBSTOJEČI GOZDARSKI INFORMACIJSKI SISTEM}

Sedanja zasnova računalniško podprtega sistema, oblikovana v začetku osemdesetih let, vsebuje take postopke zbiranja in obravnave informacij, ki naj bi omogočili izpeljavo že omenjenih nalog. V tem smislu je gozdarski informacijski sistem sestavljen iz treh medsebojno povezanih dejavnosti: popisa atributivnih znakov $\mathrm{v}$ gozdovih, odsečnih dendrometrijskih inventur in gozdarske kartografije. 
Osnovni nosilec podatkov je najmanjša organizacijska in prostorska enota, imenovana odsek. Njena povprečna površina je 12 ha, celotnemu sistemu pa daje hierarhičen značaj; pretok podatkov namreč teče od odseka do večjih enot kot so gozdnogospodarske enote in območja. Interpretacijske enote so lahko (zaradi hierarhičnega združevanja podatkov) vse omenjene površinske celote, zaradi narave gozdarskega načrtovanja pa je to največkrat gospodarski razred (ekološko-gospodarski stratum), oblikovan na ravni gozdnogospodarske enote ali območja.

\section{DATOTEKA ODSEKOV:}

- evidenčni podatki o odseku (GG območje, GG enota, katastrska občina, površina odseka, vrsta zemljišča, sektor lastništva itn.),

- požarna ogroženost,

- geografsko-rastiščni podatki (koordinati centroida, nadmorska višina, vrsta pokrajine, oblika reliefa, vrsta kamnine, tip tal itn.),

- tip rastlinske združbe in njen površinski delež v odseku,

- podatki o sestoju (stopnja ohranjenosti, zgradba sestoja),

- spravilne razmere (smer, razdalja).

DATOTEKA RAZVOJNIH FAZ (nosilec podatkov je razvojna faza znotraj odseka):

- evidenčni podatki (GGO, odsek),

- podatki o razvojnih fazah in njihovih površinskih deležih,

- sestojna zasnova, negovanost, smernice za ukrepanje,

- glavne poškodbe in njihov površinski obseg.

\section{DATOTEKA STRUKTURE LESNIH FONDOV:}

- lesna zaloga in prirastek,

- nastanek sestoja in drevesna sestava,

- kakovost in vitalnost sestoja.

Metode snemanja, s katerimi opredeljujemo posamezne znake so več ali manj izdelane, ni pa mogoče trditi, da so brez pomanjkljivosti. Pravzaprav jih karakterizirajo podobne slabosti kot jih opažamo pri vseh večjih sistemih (Berry, 1987, Golob, 1990, Hočevar, 1992, Kovač, 1992 idr.), te pa so: prešibko definirani standardi za snemanje posameznih znakov (definicije pojmov, eksaktni ključi, rangiranje, natančna navodila za snemanje znakov $v$ mejnih primerih itn.), premajhna stopnja objektivnosti, neizenačenost ocen, prešibek terenski nadzor nad posnetimi podatki, v manjši meri pa tudi nepreverjanje stanja, ki ga izkazujejo različni valorizacijski modeli $\mathrm{z}$ realnim (in-situ) stanjem.

Odsečne dendrometrijske inventure so še $v$ razvoju. Še do nedavnega je bil pretežni delež ocen pridobljen $z$ okularnimi cenitvami, danes pa se le-ta zmanjšuje, saj stroka za oceno lesnih fondov vse bolj uporablja različne 
variante objektivnejših vzorčnih metod. Na raziskovalnem področju oblikujemo koncept celostnega prostorskega informacijskega sistema, katerega integralni del bodo tudi gozdne inventure.

Tretja komponenta gozdarskega informacijskega sistema je gozdarska kartografija, ki zaenkrat še temelji na klasičnih kartografskih tehnikah. Vsebinski napredek $v$ primerjavi s prejšnjimi desetletji je očiten, pripisovati pa ga gre predvsem stiski po kakovostnem in sprotnem prikazovanju vseh vrst tematskih sporočil, ne le topografskih. V preteklem desetletju je bil namreč zasnovan sistem gozdarskih kart (Juvančič, 1988, 1990), ki je kartografsko dejavnost poenotil in vsebinsko razširil. Kljub premiku sistem ni predvidel niti rešil dejavne (aktivne) povezave podatkovnih zbirk $s$ tematskimi kartami. Avtomatsko povezavo začasno nadomešča tehnika prikazovanja grafičnih informacij $\mathbf{s}$ centroidi in je zgolj informativnega (preglednega) značaja.

\section{ORIS SISTEMA, NAMENJENEGA POPISU POŠKODOVANOSTI GOZDOV}

Popis propadanja gozdov teče $\mathrm{v}$ Sloveniji že od sredine osemdesetih let. Njegova zasnova je statistična, uporabljeni model pa je dvostopenjsko vzorčenje $v$ traktih. Trakti so praviloma postavljeni samo tam, kjer je ekosistemski tip gozd (brez premikov na terenu), kar zmanjšuje možnost pristranih površinskih ocen. Podatkovna zbirka ima naslednjo vsebino:

- evidenčni podatki,

- ekološko-rastiščni podatki,

- dendrometrijski podatki,

- podatki o poškodovanosti drevja (osutost, tip osutosti, porumenelost, tip porumenelosti, prisotnost neobičajnih vej itn.),

- podatki o lišajih.

Enota snemanja je ves trakt $s$ površino 6,25 ara, ocenjevanje znakov pa teče po dveh ravneh; del znakov, predvsem takih, ki imajo površinski (ploskovni) značaj ocenjujemo na celotni površini, znake, ki so vezani na ocenjevanje oz. merjenje dreves pa snemamo na štirih stojiščih trakta.

Večina popisnih točk (traktov) iz sistematske mreže $\mathrm{z}$ gostoto $4 \times 4 \mathrm{~km}$ je posneta že tretjič. Nekajletno variacijo vrednosti znakov (dinamiko procesa) je zato že mogoče ocenjevati s tehnikami temporalne analize. Vsebina podatkovne zbirke je nekoliko širša kot ga zahteva srednjeevropska metodologija. Tudi $\mathrm{v}$ primerjavi $\mathrm{z}$ gozdarskim informacijskim sistemom je vsebina bolj ekološko obarvana in pravzaprav predstavlja prvi poskus ekološkega monitoringa na velikoprostorski, recimo temu nacionalni ravni. 
Slika 1: Sečnje v zasebnih gozdovih, opravljene brez odkazila gozdarskega strokounjaka. Prikaz je izdelan preko centroidov odsekov.

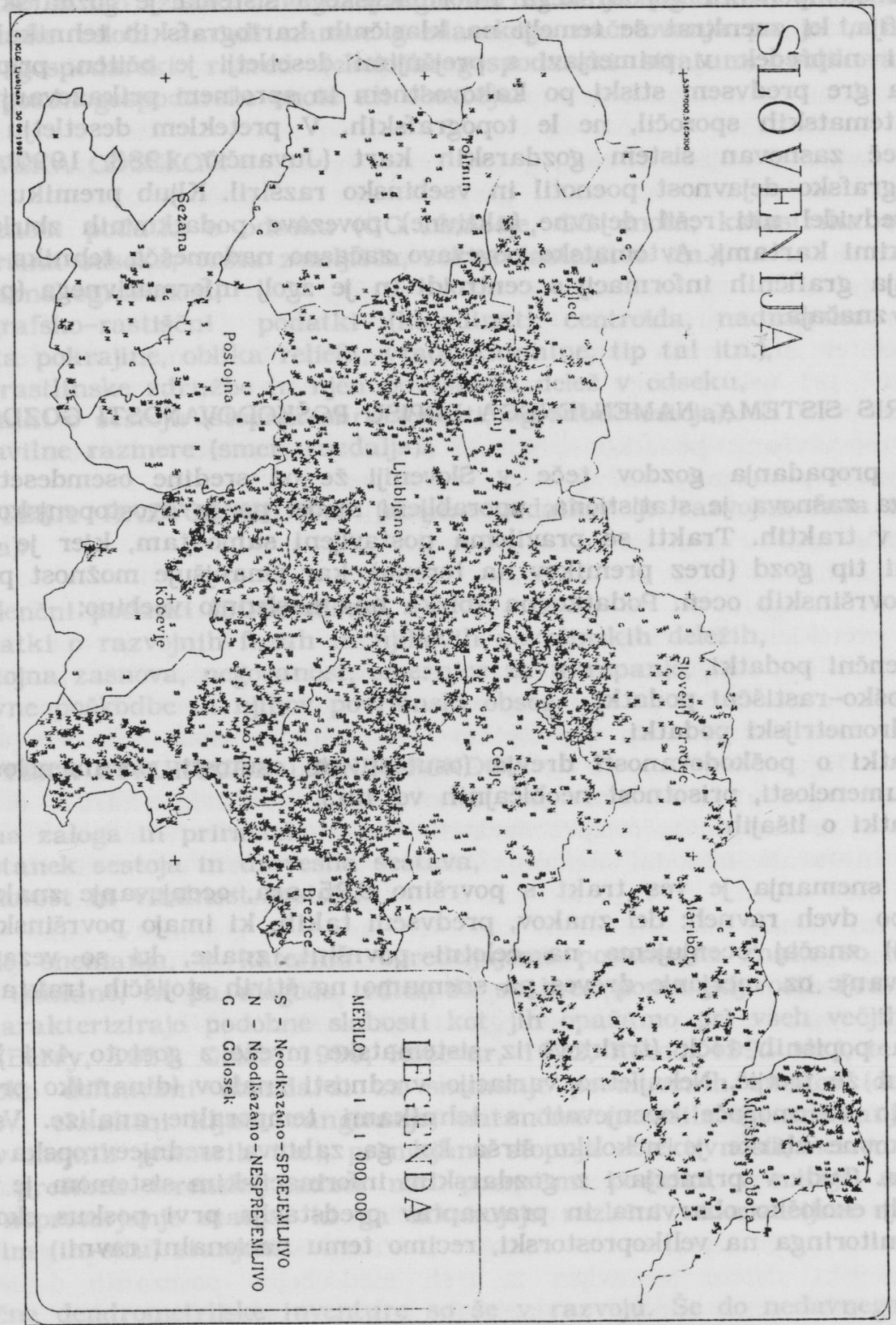




\section{IZHODIŠČA ZA ZASNOVO NOVEGA, CELOSTNEGA INFORMACIJSKEGA GOZDARSKEGA SISTEMA}

Izgradnja celostnega gozdarskega prostorskega informacijskega sistema je prednostna naloga gozdarstva in vseh strok, ki se tako ali drugače ukvarjajo s prostorom. Zaradi racionalnosti novega gozdarskega PIS je treba veliko pozornost posvetiti podsistemu za pridobivanje podatkov. Ta proces bo namreč zahteval kar $80 \%$ vse porabe časa in stroškov. Iz tega razloga bi morala biti vsa lastna snemanja skrbno načrtovana, predvsem pa se bo treba izogniti vsakemu podatkovnemu podvajanju. Če je le mogoče, bo potrebno uporabiti tuje podatkovne zbirke, ki pa bi morale biti zasnovane tako, da bo zagotovljena njihova popolna združljivost. Splošni napotek naj bo, da je $z$ minimalnim številom podatkov (velja za lastna snemanja) mogoče dobiti čim popolnejšo informacijo! Podatki morajo biti objektivni in z znano natančnostjo.

Informacijska vsebina sistema je v splošnem odvisna še od obsega, vrste, detajliranosti in natančnosti zbranih podatkov. Smiselno je zbirati samo tiste podatke, ki jih bomo kasneje tudi rabili. Merilo odločanja, ali nek znak pride $\mathrm{v}$ poštev ali ne, sta njegova kakovost in informacijska učinkovitost; učinkovit je tisti podatek, ki več koristi (mišljena je dolgoročna koristnost podatka) kot stane. Nujno je sodelovanje med načrtovalci sistema in uporabniki informacij. Pomemben parameter pri oblikovanju celostnega PIS je še njegova večdimenzionalna integrabilnost. Določena je $z$ naslednjimi elementi:

Večplastnost - ista baza podatkov naj rabi kot podlaga za odločanje na različnih ravneh gospodarjenja. V gozdarstvu so te ravni sestoj/odsek, gospodarski razred, gozdnogospodarska enota, območje/regija in republika. Praviloma so na višji ravni odločanja potrebe bolj generalizirane informacije kot na nižjih, krog uporabnikov le-teh pa je na višji ravni širši kot na nižji. Da se izognemo podvajanju, je treba oblikovati smiseln krogotok informacij.

Mnogonamenskost sistema zagotavlja informacije za ovrednotenje in za gospodarjenje $z$ vsemi pomembnimi funkcijami gozda. Pri tem velja načelo sorazmernosti med splošnokoristnimi in proizvodnimi funkcijami. V plošnem velja, da naj podatke zbira tista služba, ki je strokovno najbolj kompetentna, uporaba zbranih podatkov pa je pod določenimi pogoji splošna.

Prostorska celovitost - informacijski sistem pokriva ves gozdni prostor ne glede na lastništvo.

Multitemporalnost - sistem mora biti zasnovan $v$ smislu monitoringa, t.j. nadzora sprememb $\mathrm{v}$ gozdnem in gozdnatem prostoru. Tak pristop zagotavlja zanesljivejšo oceno dogajanja in učinkovitosti ukrepov $v$ preteklosti in tudi prognozo prihodnjega razvoja. V primeru vzorčnih snemanj naj se snemanja opravljajo na stalnih ploskvah. 
Slika 2: Model celostne integracije podatkov v PIS (Po Lund 1988).

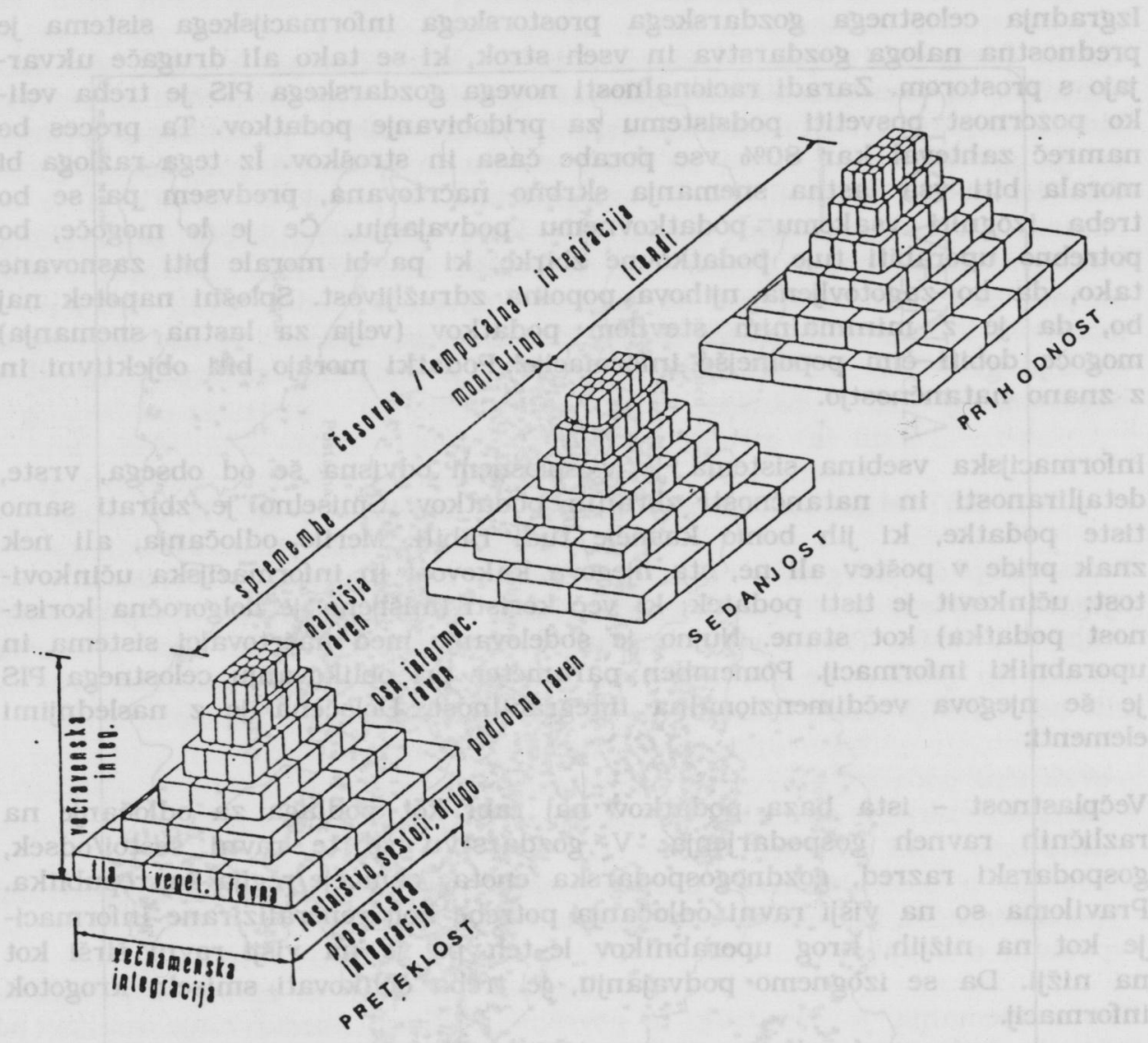

Poleg omenjenega je pri izgradnji informacijsko učinkovitega celostnega PIS potrebno upoštevati še naslednja načela:

Sodelovanje in koordinacijo, ki med snovalci informacijskega sistema in uporabniki (organi odločanja) zagotavljata pravilno izbiro podatkov, enotna pravila zbiranja podatkov na vsem prostoru, minimalne zahteve glede kakovosti podatkov, odpravo nepotrebnih podatkovnih podvajanj in dodatnih snemanj ter boljšo uporabnost končnih informacij in izkoriščanje informacijskega sistema kot celote.

Standardizacijo in inovativnost, ki odločata o enoličnosti podatkovnih zbirk in sistemski prožnosti. Pomen podatkov mora biti natančno defi- 
niran. Samo dosledno upoštevanje teh elementov dovoljuje poljubno kombiniranje in primerjanje informacij (natančni šifranti, pravila snemanja). Hkrati mora sistem ostati dovolj prožen, da so mogoče izboljšave.

Objektivnost in natančnost je pomembna zahteva, ki zagotavlja uporabo podatkov iz različnih virov in oceno zanesljivosti odločitev (navedeno mora biti merilo zajemanja podatkov, natančnost snemanja/odčitavanja). Zahteva je še posebej pomembna zaradi današnje, človeku odtujene računalniške obdelave podatkov.

Kontrola in osebna odgovornost zagotavljata kakovost podatkov $\mathrm{v}$ okviru izdelanih pravil. Vsak načrt snemanja mora že na samem začetku opredeliti način kontrole in odgovorne osebe. Sistem zajemanja podatkov mora biti zasnovan prijazno za izvajalca in mora $v$ čim večji možni meri preprečevati možnost pojavljanja napak (npr. izbira sistema za digitalizacijo kart, t.j. opravila, $k i$ bo $v$ bližnji bodočnosti narekovalo veliko porabo časa).

Kakovost celotnega PIS je odvisna predvsem od kakovosti vhodnih podatkov. Tega se $\mathrm{v}$ praksi pogosto premalo zavedamo. Podatki morajo biti objektivni, ponovljivi, znana pa mora biti tudi njihova točnost. To lahko zagotovimo le $\mathbf{s}$ primernim pristopom in pripravo dela, ki obsega:

- do vseh podrobnosti izdelan in organiziran sistem snemanja podatkov,

- temeljito uvajanje in trening snemalnega osebja,

- kontrolo dela na terenu ter spontano logično in končno kontrolo podatkov in rezultatov.

\section{NADZOR GOZDNEGA EKOSISTEMA IN GOZDNATE KRAJINE}

Zaradi čedalje bolj obremenjenega okolja in propadanja gozdov je potrebno težišče dela prenesti na učinkovit monitoring dogajanj $\mathrm{v}$ gozdu in gozdnem prostoru. Zasnova sodobnega prostorskega informacijskega sistema mora poleg integracije dosedanjega sistema zbiranja podatkov v gozdarstvu upoštevati vedno bolj poudarjeno mnogonamensko vlogo gozda in naš sonaraven, prostorsko izredno razčlenjen način gospodarjenja.

Ideja sonaravnosti je presegla prizadevanja po varovanju prvobitnosti in poslednjih oaz ohranjene narave, posebno $\mathrm{v}$ gozdu je vtkana $\mathrm{v}$ celoten prostor človekove dejavnosti (Amer, Utschick, 1982; Volk, 1988; Schirmer, 1991). Sklicevanje na resnico, da je gozd med vsemi elementi kulturne krajine naravi najbližji, ne zadošča več. Gozdarstvo postaja pomemben oblikovalec biotopov tudi $\mathrm{v}$ deželah, kjer je doslej gozd predstavljal predvsem tradicionalen vir surovin in zatočišče ali bivališče divjadi (Hanstein, 1992, Brooks, Grant, 1992).

Ob analizi gozdnega prostora in gozdnate krajine ne razmejujemo gozdnih 
Slika 3: Ohranjenost gozdnih sestojev $v$ gozdnogospodarski enoti Mozelj na Kočeuskem. Meje enote so vrisane tudi $v 3 d$ prikaz modelnega območja.

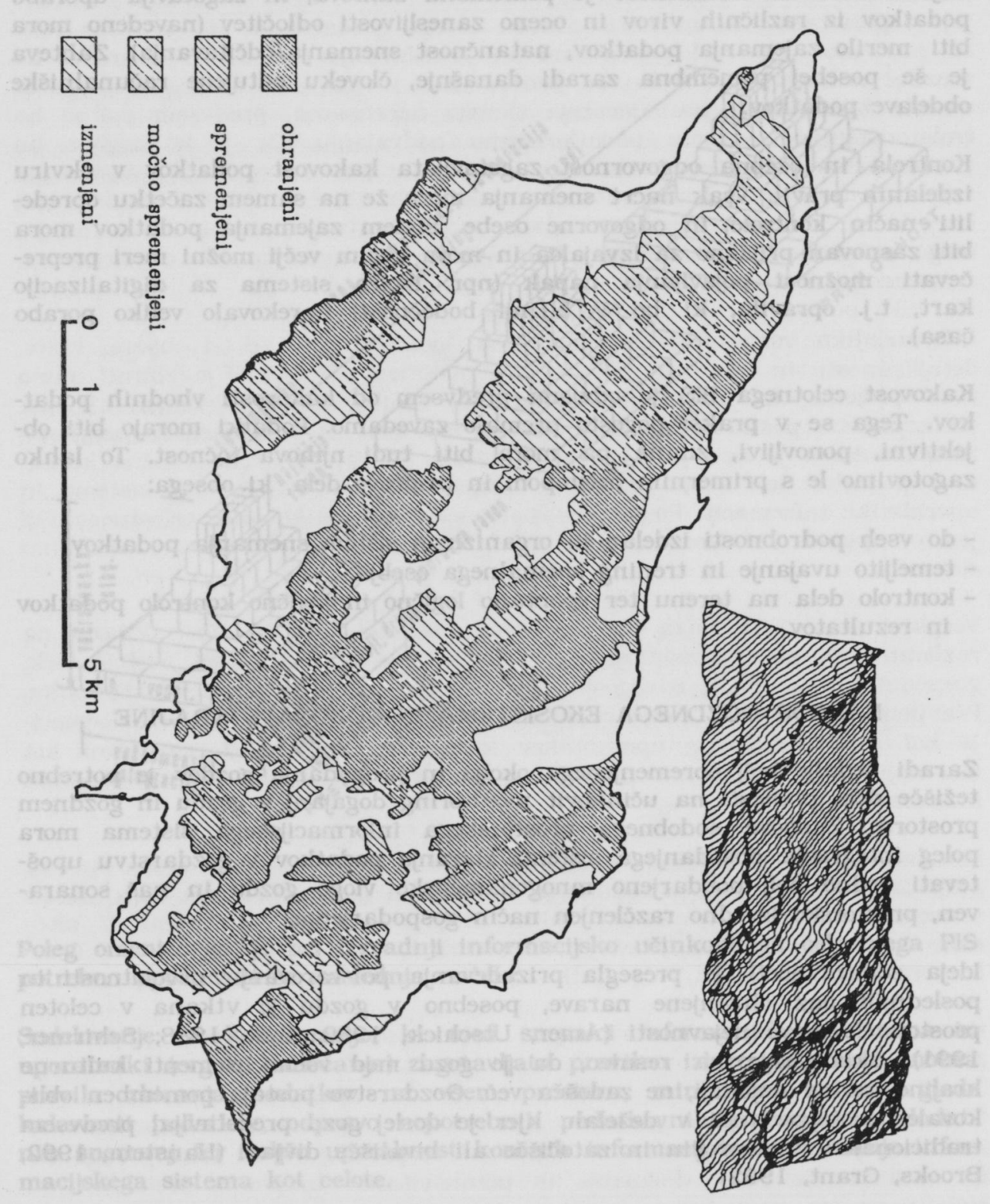


sestojev le kot osrednjih homogenih nosilcev podatkov in informacij, pomembni postajajo tudi znaki:

- sonaravne zgradbe sestojev,

- strukturne in vrstne pestrosti,

- redkosti rastlinskih vrst.

Gozdni sestoj tako opredelimo tudi glede na njegov ekološki potencial. Na nivoju gozdnega ekosistema in gozdnate krajine pa so pomembni znaki prostorske pestrosti, mozaične prepletenosti posameznih rab prostora, oblike in dolžine gozdnega roba, ohranjenosti, sklenjenosti in povezanosti gozdnega prostora.

Teh znakov doslej nismo upoštevali, ker jih pred uveljavitvijo prostorskih informacijskih sistemov niti ni bilo mogoče ocenjevati in analizirati. Nujne so bile poenostavitve, pri katerih smo bodisi privzeli, da je prostor homogen, ali pa smo sklepali predvsem o linearnih povezavah $\mathrm{v}$ okolju.

Predstavljena izhodišča bomo uveljavili v okviru projekta "Analiza naravnih danosti in ocena razvojnih potencialov kočevske krajine". Temeljni cilji projekta so:

- izdelati zasnovo prostorskega informacijskega sistema za kočevsko regijo in ga povezati $\mathrm{z}$ dosedanjim informacijskim sistemom,

- v sodelovanju z GG Kočevje oblikovati gozdarski prostorski informacijski sistem,

- analizirati naravne in antropogene danosti za oblikovanje krajinskega parka.

Ob privzetih informacijskih plasteh bo osrednji del projekta usmerjen $\mathrm{k}$ oblikovanju sklopa gozd in gozdarstvo. Pri njegovem oblikovanju bomo poleg že predstavljenih virov uporabili naslednje vire podatkov in informacij:

- terensko zbiranje podatkov $\mathrm{v}$ okviru gozdne inventure,

- aerosnemanje $z$ infrardečim barvnim filmom $v$ merilu 1:35000 iz leta 1992, letalske posnetke cikličnega aerosnemanja Slovenije (CAS) in posebnega snemanja iz leta 1965 ,

- izsek iz satelitskega posnetka LANDSAT TM iz leta 1992.

Doslej smo na slovenskem s terenskim zbiranjem podatkov na vzorčnih ploskvah kontrolne vzorčne metode ocenjevali predvsem dendrometrijske znake (Hočevar 1990), zato bo metoda dopolnjena $z$ obsežnejšo oceno sestojne zgradbe in opisom krajinskih elementov. Tu bomo podrobno primerjali terenske znake $z$ njihovo preslikavo na letalskih posnetkih in izdelali interpretacijski ključ rabe prostora. Oblikovali bomo način razvrščanja gozdnih sestojev, ki bo upošteval dosedanji koncept členitve gozdnega prostora, prilagoditi pa ga bo potrebno različnim nivojem analize prostora. Tu ne gre za generalizacijo podatkov $\mathrm{v}$ kartografskem smislu, temveč za oblikovanje ključev, prilagojenih različnim merilom oziroma nivojem prostorske členit- 
ve. Z določitvijo izhodišč za velikoprostorski nadzor okolja bo mogoče oblikovati tudi načela za primerjavo med posameznimi regijami. Povezave med znaki, s katerimi opredeljujemo značilnosti gozdnega ekosistema in gozdnate krajine, se namreč spreminjajo po posameznih krajinskih tipih, kar onemogoča neposredno primerjavo med regijami ali drugačnimi prostorskimi celotami.

V sklepnem delu raziskave bomo $z$ obdelavo satelitskega posnetka prenesli izsledke iz modelnega območja v širši prostor kočevske. Uporaba satelitskih posnetkov za velikoprostorski nadzor zahteva temeljitejšo raziskavo, toda ob oblikovanju informacijskega sistema o okolju in izrednih možnosti zaporednih snemanj (multitemporalnost nadzora), ki jih ponujajo satelitska snemanja, bomo skušali vsaj določiti mesto te tehnike v velikoprostorskem nadzoru gozdnega ekosistema in gozdnate krajine na slovenskem.

\section{LITERATURA IN VIRI}

Amer, U., Utschick, H., 1982: Methodische Ueberlegungen fuer eine Biotopkartierung im Wald, Forstw. Cbl. 101, 60-68.

Berry, J.K., 1987: Computer - assisted map analysis: potential and pitfals, Photogrammetric Engineering and Remote Sensing, 53, 10, 1405-1410.

Brooks, D.J., Grant, G.E., 1992: New Approaches to Forest Management, Journal of Forestry, 1, 25-28.

Funkl, L., 1979: Temeljne poteze v razvoju urejanja gozdov na Slovenskem, Gozdnogospodarsko načrtovanje - integralni del družbenega planiranja, Gozdarski študijski dnevi 1977, Ljubljana, IGLG, 7-14.

Golob, A., 1990: Možnosti razvoja računalniško podprtega prostorskega informacijskega sistema $v$ slovenskem gozdarstvu, Gozdarski vestnik, Ljubljana, 48, 5, 261-266.

Golob, A., 1992: Eko-razvoj, Naši razgledi (21. februar), Ljubljana, 119

Hanstein, U., 1992: Vollflaechige Waldbiotopkartierung als Teil der Forsteinrichtung, Forst und Holz, 14, 17, 531-533.

Hočevar, M., 1990: Ugotavljanje stanja in razvoja gozdov s kontrolno vzorčno metodo, Univerza v Ljubljani, BF, Oddelek za gozdarstvo, Zbirka referatov in navodila za pripravo in snemanje na stalnih vzorčnih ploskvah.

Hočevar, M., 1992: Osnove in zahteve prostorskih informacijskih sistemov, Pomen stanje in prihodnji razvoj gozdarske prostorske informatike, IGLG, Ljubljana, 1-5.

Juvančič, M., 1988: Funkcije gozdarskih kart pri gospodarjenju z gozdovi, FAGG, Ljubljana, disertacija, 266 s.

Juvančič, M., 1990: Vprašalnik - sistem gozdarskih kart 1990, BF Oddelek za gozdarstvo, Ljubljana, mnscr., $10 \mathrm{~s}$. 
Kovač, M., 1992: Analiza gozdarskega informacijskega sistema, Pomen stanje in prihodnji razvoj gozdarske prostorske informatike, IGLG, Ljubljana, 15-21.

Lund, G., 1988: A Primer on Integrating Resource Inventories, US Dep.of Agricult., Gen.Tech. Report WO-49, 64 s.

Mikulič, V., 1983: Računalniško podprt informacijski sistem v Sloveniji, IGLG, Ljubljana, mnscr., $6 \mathrm{~s}$.

Mikulič, V., 1987: Opis podatkov v skupni zbirki podatkov za gozdarski IS, IGLG, Ljubljana, mnscr., 24 s.

Mikulič, V., 1992: Pomen, stanje in prihodnji razvoj gozdarskega informacijskega sistema $z$ vidika obravnavanja prostorskih podatkov, Pomen stanje in prihodnji razvoj gozdarske prostorske informatike, IGLG, Ljubljana, 7-8.

Schirmer, C., 1991: Waldbiotopbewertung Heilbronn, Biotopschutz und Forstwirtschaft im kollinen Neckerland, Mitteilungen der Forstlichen Versuchs- und Forschungsanstalt, Baden-Wuerttemberg, Heft 164, 109.

Volk, H., 1988: Die Waldbiotopkartierung, Ein Ansatz zur Erfassung des Naturschutzwertes der Waelder, AFZ, 4, 55-62. 